\title{
Endothelin-1 activates Homer 1 a expression via mitogen-activated protein kinase in cardiac myocytes
}

\author{
TAKAHIRO KAWAMOTO $^{1}$, KIYONORI TOGI ${ }^{1}$, RYOKO YAMAUCHI ${ }^{1}$, YOSHINORI YOSHIDA $^{1}$, \\ YASUHIRO NAKASHIMA ${ }^{1}$, TORU KITA ${ }^{1}$ and MAKOTO TANAKA ${ }^{1,2}$ \\ ${ }^{1}$ Department of Cardiovascular Medicine, Graduate School of Medicine, Kyoto University; \\ ${ }^{2}$ Department of Social Service, Kyoto University Hospital, Kyoto, Japan
}

Received January 13, 2006; Accepted February 28, 2006

\begin{abstract}
Homer proteins are a family of scaffolding proteins which may play an important role in calcium signaling by facilitating the assembly of signaling complexes in neuronal cells. Among the three splice variants of Homer 1, Homer 1 a is rapidly up-regulated by neural stimulation and may regulate the disassembly of signaling complexes mediated by Homer proteins. In spite of its potential importance in calcium signaling, the regulation of Homer $1 a$ expression in cardiac myocytes has never been investigated. In this study, we examined the regulation of Homer $1 a$ expression in cardiac myocytes. Homer la was significantly up-regulated by several hypertrophic agonists, including endothelin-1 (ET-1), phenylephrine, isoprotenerol and angiotensin-II, and ET-1 most strikingly induced Homer $1 a$ expression. The induction of Homer $1 a$ expression by ET-1 peaked at $2 \mathrm{~h}$ and inhibitors for mitogen-activated/extracellular signal regulated kinase (MEK) significantly suppressed the induction of Homer la. This study first clarified the regulation of Homer la expression in cardiac myocytes and demonstrated that ET-1 induced Homer la expression through the mitogen-activated protein kinase pathway.
\end{abstract}

\section{Introduction}

Homer proteins are a family of scaffolding proteins, characterized by N-terminal Enabled/Vasp homology (EVH-1) and coiled-coil domains (1). The EVH-1 domain binds a prolinerich motif present in key components of synaptic signal transduction pathways including the metabolic glutamate receptors, mGluR1a and mGlu5a/b, inositol-1,4,5-triphosphate (IP3) receptors and the Shank family of scaffolding proteins

Correspondence to: Dr Makoto Tanaka, Department of Cardiovascular Medicine and Department of Social Service, Kyoto University Hospital, 54 Shogoin-Kawahara-cho, Sakyo-ku, Kyoto 606-8507, Japan

E-mail: makoto@kuhp.kyoto-u.ac.jp

Key words: Homer 1, endothelin-1, cardiac myocyte, transcriptional activation, MAP kinase
$(2,3)$. Homer proteins dimerize with other Homer proteins through the coiled-coil domain and mediate the interaction between cellular proteins that directly or indirectly bind to Homer (4). For example, N-methyl-D-aspartate (NMDA) receptors are associated with Shank via other scaffolding proteins and the ability of Homer proteins to form multimers allows for a physical and functional link between mGluRs, IP3 receptors and NMDA receptors in neuronal cells (1). Thus, Homer proteins are implicated as adaptor proteins that facilitate a physical association between cell surface receptors and intracellular store calcium channels.

Homer 1 comprises three splice variants: Homer $1 a, 1 b$ and $1 c(4,5)$. While Homer $1 b$ and $1 c$ are constitutively expressed, Homer $1 a$ is an immediate early gene, induced by synaptic activities including administration of glutamate or brain-derived neurotrophic factor, tetanic stimuli and electroconvulsive seizure $(2,5,6)$. Homer $1 a$, encoded by a prematurely terminated transcript and lacking the coil-coiled domain (7), may act in a dominant negative fashion by interfering with multimerization and disassembling signaling complexes (1). Indeed, Homer $1 a$ overexpression in neuronal cells attenuated mGluR-evoked intracellular calcium release, suggesting that Homer 1a may regulate coupling between extracellular signals and calcium release from the ER (3). On the other hand, Homer 1a also exerts constitutive activity by disassembling signaling complexes depending on the situation. It was reported that TRPC1, a non-specific cationic channel, could bind to Homer proteins and that the disassembly of a TRPC1-Homer-IP3R complex resulted in channels that were constitutively active (8). Expression of Homer la was also shown to induce constitutive activity in mGluR1a and mGluR5 (9).

Homer 1 is expressed in the heart as well as in the brain $(4,10)$. Considering its potential function in neuronal cells, Homer 1a may be also involved in calcium signaling by mediating the interaction between cell surface receptors and ER calcium channels in cardiac myocytes, which plays an important role in cardiac hypertrophy $(11,12)$. However, regulation of Homer $1 a$ expression in the heart is totally unknown. In this study, we investigated the induction and regulation of Homer 1a expression by extracellular signals in the heart using cultured rat neonatal cardiac myocytes. We found that the three splice variants of Homer 1 were all expressed in cardiac myocytes and Homer 1 a expression was induced by several hypertrophic agonists. Endothelin-1 (ET-1) 
most strikingly up-regulated Homer la expression and the induction by ET-1 was mediated by the mitogen-activated protein kinase pathway.

\section{Materials and methods}

Materials. Endothelin-1, angiotensin II, phenirephrin and isoproterenol were purchased from Sigma (St. Louis, MO), and all inhibitors were from WAKO (Tokyo, Japan).

Cell culture. Primary ventricular cardiac myocytes were prepared from 2- to 3-day-old Sprague-Dawley rats as described previously (13). Cells were plated at a density of $2 \times 10^{4}$ cells $/ \mathrm{cm}^{2}$ on gelatin-coated dishes and incubated in Dulbecco's modified Eagle's medium (DMEM) with 10\% fetal calf serum for $24 \mathrm{~h}$. All experiments were performed in serum-free conditions after $24 \mathrm{~h}$ of incubation in serum-free DMEM.

Northern blot analysis. Total RNA was purified from cultured cardiac myocytes using TRIzol reagent (Life Technologies, Gaithersburg, MD). Total RNA (20 $\mu \mathrm{g})$ was electrophoresed in $1.0 \%$ denaturing (folmaldehyde) agarose gels and blotted onto nylon membrane. After hybridization with a [ $\left.{ }^{32} \mathrm{P}\right]$-labeled probe, the membrane was washed and exposed to a BAS 5000 Imaging Plate (Fuji, Tokyo, Japan). Densitometry was performed using NIH image. A full-length cDNA for Homer 1a was used as a probe.

Cell stimulation and inhibitor assay. After incubation in serum-free DMEM for $24 \mathrm{~h}$, cardiac myocytes were washed and maintained in DMEM for $20 \mathrm{~min}$. The cells were stimulated by the addition of endothelin-1, angiotensin II, phenirephrin or isoproterenol. After treatment for indicated times, RNA was extracted for Northern blot analysis. Inhibitors were added $30 \mathrm{~min}$ before stimulation by endothelin-1.

Statistical analysis. Data were analyzed by one-factor ANOVA followed by Fisher's PLSD as a post-hoc test.

\section{Results}

Homer 1 expression in cultured neonatal cardiac myocytes. We first examined the expression of Homer 1 transcripts in cardiac myocytes. Northern blotting using full-length cDNA for Homer $1 a$ as a probe revealed that all three splice variants of Homer 1 were expressed in cardiac myocytes (Fig. 1A). However, the expression level of Homer la was very low at basal conditions (Fig. 1A). We next examined whether hypertrophic agonists could induce Homer la expression. Interestingly, Homer $1 a$ expression was significantly upregulated by endothelin-1 (ET-1), phenylephrine, isoprotenerol and angiotensin-II (Ang II) (Fig. 1). Since ET-1 most strikingly activated Homer 1a expression, we examined the regulation of Homer $1 a$ expression by ET-1 in cardiac myocytes in subsequent experiments.

ET-1 regulates Homer la expression through MEK/ERK activation. We investigated the time course of Homer 1 a induction by ET-1 in cardiac myocytes. Homer $1 a$ mRNA was
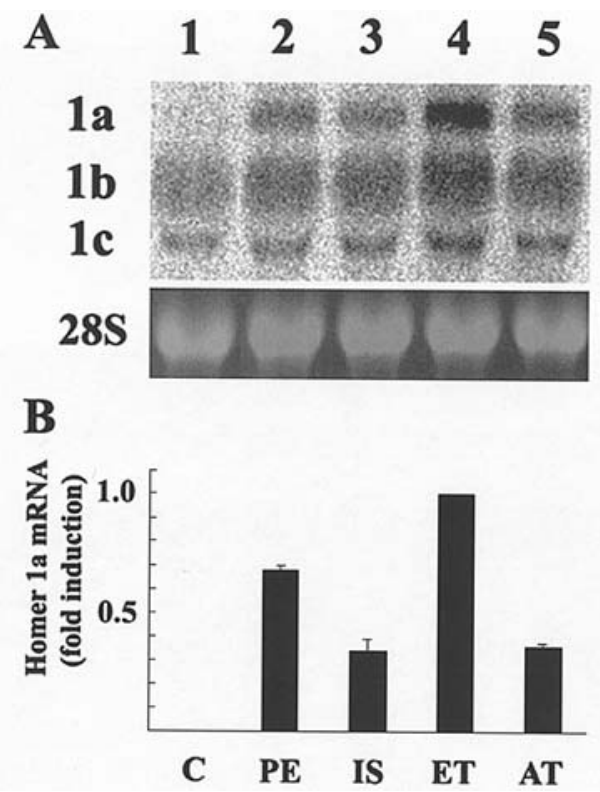

Figure 1. Expression of Homer 1 in cardiac myocytes. Cardiac myocytes expressed all three splice variants of Homer 1. The immediate early gene product, Homer 1a, was induced by all hypertrophic agonists examined. ET-1 most strikingly up-regulated Homer $1 a$ expression. (A) A representative blot showing induction of Homer $1 a$ by several agonists. Cells were incubated with $50 \mu \mathrm{M}$ phenylephrine (lane 2, PE), $10 \mu \mathrm{M}$ isoproterenol (lane 3, IS), $0.1 \mu \mathrm{M}$ ET-1 (lane 4, ET) or $0.1 \mu \mathrm{M}$ Ang II (lane 5, AT) for $2 \mathrm{~h}$. Lane 1, control (without any agonists). Ethidium bromide staining of $28 \mathrm{~S}$ rRNA as a reference of RNA loading. (B) Homer 1a mRNA induction by several agonists. Data are shown as fold induction compared with cells incubated with ET-1. The mean \pm SD of three independent experiments is shown.

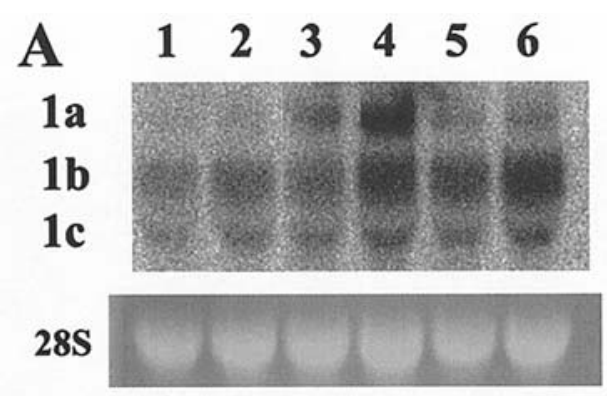

B

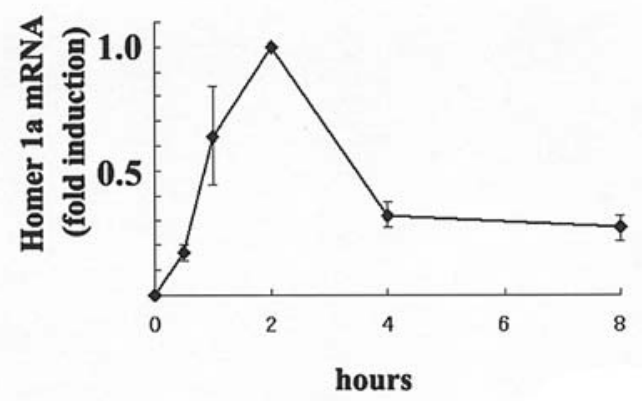

Figure 2. The time course of Homer $1 a$ mRNA induction by ET-1. (A) A representative blot showing the time course of Homer 1 a mRNA induction by ET-1. Cells were incubated with $0.1 \mu \mathrm{M}$ ET-1 for the indicated times. Lane 1,0 h; lane 2, $0.5 \mathrm{~h}$; lane 3, $1 \mathrm{~h}$; lane 4, $2 \mathrm{~h}$; lane 5, $4 \mathrm{~h}$; lane 6, $8 \mathrm{~h}$. Ethidium bromide staining of $28 \mathrm{~S}$ rRNA as a reference of RNA loading. (B) Temporal induction patterns of Homer $1 a$ mRNA by ET-1. Data are shown as fold induction compared with cells incubated with ET-1 for $2 \mathrm{~h}$ and represent the mean \pm SD of three independent experiments. 

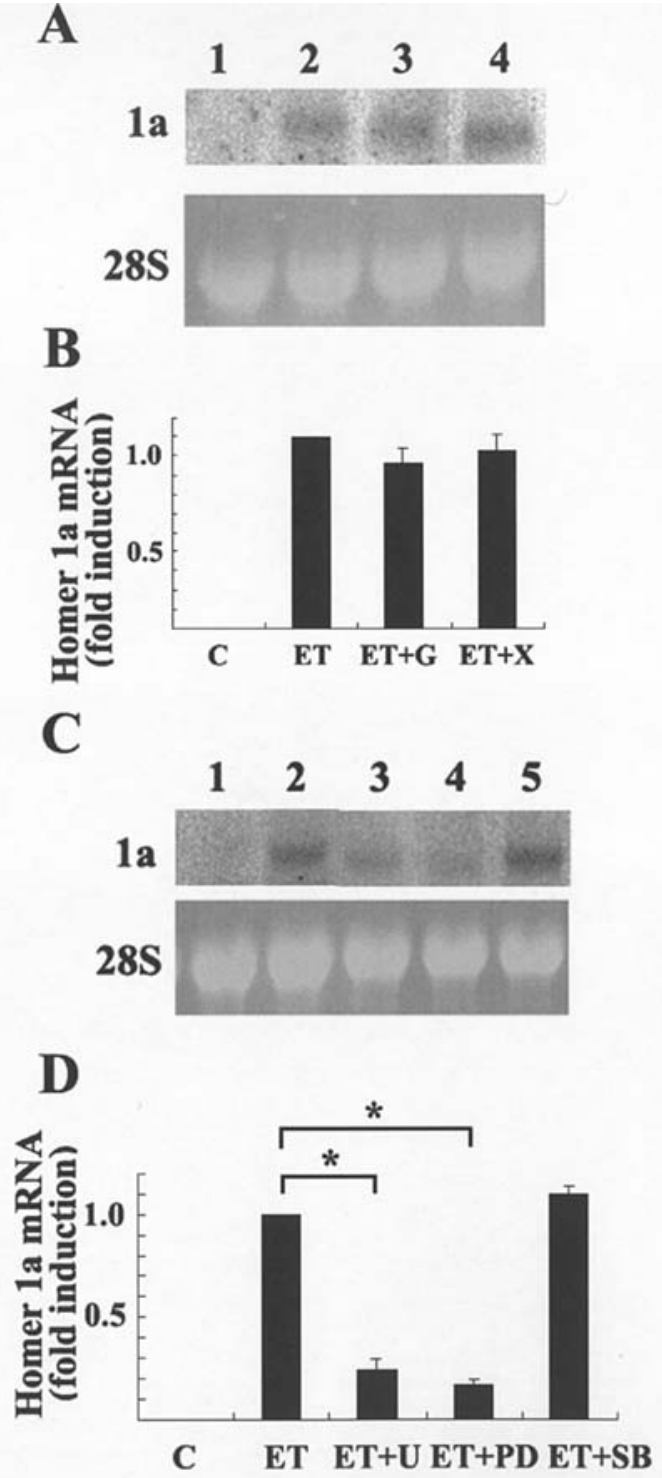

Figure 3. Homer 1a mRNA induction by ET-1 was blocked by inhibition of MEK. (A and B) Inhibition of PKC or IP3 did not affect Homer 1a induction by ET-1. Cells were preincubated with $0.1 \mu \mathrm{M}$ GFX (lane 3, ET+G) or $2 \mu \mathrm{M}$ xestospongin $\mathrm{C}$ (lane $4, \mathrm{ET}+\mathrm{X}$ ) for $30 \mathrm{~min}$ and further incubated with $0.1 \mu \mathrm{M}$ ET-1 for 2 h. (A) A representative blot. Lane 1, control (C); lane 2, ET-1 alone (ET); lane 3, pretreatment with GFX $(\mathrm{ET}+\mathrm{G})$; lane 4, pretreatment with xestospongin $\mathrm{C}(\mathrm{ET}+\mathrm{X})$. Ethidium bromide staining of $28 \mathrm{~S}$ rRNA as a reference of RNA loading. (B) Data are shown as fold induction compared with cells incubated with ET-1 alone. The mean \pm SD of three independent experiments is shown. (C and D) Homer $1 a$ induction by ET-1 was blocked by inhibition of MEK. Cells were preincubated with $5 \mu \mathrm{M} \mathrm{U} 0126,30 \mu \mathrm{M}$ PD98059 or $5 \mu \mathrm{M}$ SB203580 for $30 \mathrm{~min}$ and further incubated with $0.1 \mu \mathrm{M}$ ET-1 for $2 \mathrm{~h}$. Lane 1, control (C); lane 2, ET-1 alone (ET); lane 3, pretreatment with U0126 (ET+U); lane 4, pretreatment with PD98059 (ET+PD); lane 5, pretreatment with SB203580 (ET+SB). Ethidium bromide staining of $28 \mathrm{~S}$ rRNA as a reference of RNA loading. (C) A representative blot. (D) Data are shown as fold induction compared with cells incubated with ET-1 alone. The mean \pm SD of three independent experiments is shown. *Significantly different from cells treated with ET-1 alone (ET) by Fisher's PSD test.

induced as early as $1 \mathrm{~h}$ after stimulation with ET-1 (Fig. 2). The induction peaked by $2 \mathrm{~h}$ and persisted up to $8 \mathrm{~h}$ (Fig. 2).

In the heart, the $\mathrm{ET}_{\mathrm{A}}$ receptor is the principal receptor for ET-1 and is coupled to the Gq group of heterotrimeric G proteins $(14,15)$. Binding of ET-1 to the $\mathrm{ET}_{\mathrm{A}}$ receptor results in the activation of protein kinase $\mathrm{C}(\mathrm{PKC})$ by diacylglycerol and release of $\mathrm{Ca}^{2+}$ from the ER by IP3 (14). We then examined the roles of PKC and IP3 in Homer $1 a$ induction. However, inhibition of PKC $(0.1 \mu \mathrm{M}$ GFX) or the IP3 receptor $(2 \mu \mathrm{M}$ xestospongin $\mathrm{C}$ ) had no effect on Homer la induction, suggesting that the activation of PKC or $\mathrm{Ca}^{2+}$ release from the IP3 receptor was not involved in the induction of Homer $1 a$ by ET-1 (Fig. 3A and B).

In addition to the activation of the $\mathrm{Gq}$ class of $\mathrm{G}$ proteins, ET-1 rapidly and transiently stimulates the extracellular signal-regulated kinase (ERK) cascade in cardiac myocytes (14). For this cascade, mitogen-activated protein kinase kinase kinase (MAPKKK) is Raf and MAPKK is mitogenactivated/extracellular signal regulated kinase (MEK) (14). We thus investigated the effects of MEK inhibition on Homer 1 a induction by ET-1. Although inhibition of p38 $(5 \mu \mathrm{M}$ SB203580) showed no effects, two kinds of MEK inhibitors (5 $\mu \mathrm{M}$ U0126 or $30 \mu \mathrm{M}$ PD98059) significantly suppressed the induction of Homer 1a, demonstrating that ET-1 induced Homer $1 a$ expression through activation of the MEK-ERK pathway (Fig. 3C and D).

\section{Discussion}

Calcium signaling in response to extracellular signals plays an important role in cardiac hypertrophy $(11,12,16)$. Because of their potential importance in calcium signaling in neuronal cells, we hypothesized that Homer proteins may be also involved in signal transduction mediating cardiac hypertrophy. However, the expression pattern of Homer in cardiac myocytes has never been examined. In this study, we focused on the expression pattern of the immediate early gene (IEG) product, Homer $1 a$, because we anticipated that induction of Homer 1a may be involved in feedback regulation of hypertrophic signals. Interestingly, all hypertrophic agonists examined induced expression of Homer la, suggesting that Homer la induction may be a common phenomenon associated with hypertrophic signal activation.

The mitogen-activated protein kinase (MAPK) pathway regulates cellular proliferation and hypertrophy $(14,17)$. Interestingly, ET-1 activated Homer 1 la expression via the MEK-ERK cascade, which also mediates hypertrophic signals $(11,18,19)$, suggesting that Homer 1a may be involved in the modulation of hypertrophic signals. Westhoff et al reported that Homer $1 \mathrm{c}$ decreased the ryanodine type 2 receptor (RyR2)-mediated $\mathrm{Ca}^{2+}$ release from microsomes prepared from the sarcoplasmic reticulum (SR) of rat cardiac myocytes but that Homer 1a reversed the effect of Homer 1c, indicating that aggregation of a part of RyR2 population into signaling complexes by Homer proteins may regulate the release of $\mathrm{Ca}^{2+}$ from intracellular stores in cardiac myocytes (20). Therefore, Homer 1a, induced via the MEK-ERK cascade, may regulate disassembly of signaling complexes including SR channels and modulate $\mathrm{Ca}^{2+}$ homeostasis, thus mediating crosstalk between the MAP kinase and $\mathrm{Ca}^{2+}$ signaling pathways during cardiac hypertrophy.

In summary, Homer $1 a$ was induced by several hypertrophic signals and ET-1 most strikingly up-regulated Homer la expression in cardiac myocytes. Homer la induction by ET-1 was mediated through the MEK-ERK cascade. Homer $1 a$ induction may modulate hypertrophic signals in 
cardiac myocytes and Homer proteins may represent a potential therapeutic target in cardiac hypertrophy.

\section{Acknowledgements}

We gratefully acknowledge Keiko Kobayashi for technical assistance. This work was supported by research grants from the Ministry of Education, Science, Sports, and Culture of Japan (15590738, 12CE2006 and 13307034), research grants from the Ministry of Health, Labor, and Welfare of Japan (Comprehensive Research on Aging and Health Grant H14-choju-012), and grants provided by the Ichiro Kanehara Foundation, the Takeda Science Foundation and the Suzuken Memorial Foundation.

\section{References}

1. Thomas U: Modulation of synaptic signalling complexes by Homer proteins. J Neurochem 81: 407-413, 2002.

2. Brakeman PR, Lanahan AA, O'Brien R, Roche K, Barnes CA, Huganir RL and Worley PF: Homer: a protein that selectively binds metabotropic glutamate receptors. Nature 386: 284-288, 1997.

3. Tu JC, Xiao B, Yuan JP, Lanahan AA, Leoffert K, Li M, Linden DJ and Worley PF: Homer binds a novel proline-rich motif and links group 1 metabotropic glutamate receptors with IP3 receptors. Neuron 21: 717-726, 1998.

4. Xiao B, Tu JC, Petralia RS, Yuan JP, Doan A, Breder CD, Ruggiero A, Lanahan AA, Wenthold RJ and Worley PF: Homer regulates the association of group 1 metabotropic glutamate receptors with multivalent complexes of homer-related, synaptic proteins. Neuron 21: 707-716, 1998.

5. Sato M, Suzuki K and Nakanishi S: NMDA receptor stimulation and brain-derived neurotrophic factor upregulate homer 1a mRNA via the mitogen-activated protein kinase cascade in cultured cerebellar granule cells. J Neurosci 21: 3797-3805, 2001.

6. Kato A, Ozawa F, Saitoh Y, Hirai K and Inokuchi K: Vesl, a gene encoding VASP/Ena family related protein, is upregulated during seizure, long-term potentiation and synaptogenesis. FEBS Lett 412: 183-189, 1997.
7. Bottai D, Guzowski JF, Schwarz MK, Kang SH, Xiao B, Lanahan A, Worley PF and Seeburg PH: Synaptic activityinduced conversion of intronic to exonic sequence in Homer 1 immediate early gene expression. J Neurosci 22: 167-175, 2002.

8. Yuan JP, Kiselyov K, Shin DM, Chen J, Shcheynikov N, Kang SH, Dehoff MH, Schwarz MK, Seeburg PH, Muallem S, et al: Homer binds TRPC family channels and is required for gating of TRPC1 by IP3 receptors. Cell 114: 777-789, 2003.

9. Ango F, Prezeau L, Muller T, Tu JC, Xiao B, Worley PF, Pin JP, Bockaert J and Fagni L: Agonist-independent activation of metabotropic glutamate receptors by the intracellular protein Homer. Nature 411: 962-965, 2001.

10. Sandona D, Tibaldo E and Volpe P: Evidence for the presence of two homer 1 transcripts in skeletal and cardiac muscles. Biochem Biophys Res Commun 279: 348-353, 2000.

11. McKinsey TA and Olson EN: Cardiac hypertrophy: sorting out the circuitry. Curr Opin Genet Dev 9: 267-274, 1999.

12. Frey N, McKinsey TA and Olson EN: Decoding calcium signals involved in cardiac growth and function. Nat Med 6: 1221-1227, 2000.

13. Sadoshima J, Jahn L, Takahashi T, Kulik TJ and Izumo S: Molecular characterization of the stretch-induced adaptation of cultured cardiac cells. An in vitro model of load-induced cardiac hypertrophy. J Biol Chem 267: 10551-10560, 1992.

14. Sugden $\mathrm{P}$ and Bogoyevitch M: Endothelin-1-dependent signaling pathways in the myocardium. Trends Cardiovasc Med 6: 87-94, 1996.

15. Belloni AS, Guidolin D, Ceretta S, Bova S and Nussdorfer GG: Acute effect of ischemia on adrenomedullin immunoreactivity in the rat heart: an immunocytochemical study. Int J Mol Med 14: 71-73, 2004

16. Molkentin JD, Lu JR, Antos CL, Markham B, Richardson J, Robbins J, Grant SR and Olson EN: A calcineurin-dependent transcriptional pathway for cardiac hypertrophy. Cell 93: 215-228, 1998

17. Seger $\mathrm{R}$ and Krebs EG: The MAPK signaling cascade. FASEB J 9: 726-735, 1995 .

18. Clerk A and Sugden PH: Activation of protein kinase cascades in the heart by hypertrophic $\mathrm{G}$ protein-coupled receptor agonists. Am J Cardiol 83: 64H-69H, 1999.

19. Bogoyevitch MA: Signalling via stress-activated mitogenactivated protein kinases in the cardiovascular system. Cardiovasc Res 45: 826-842, 2000.

20. Westhoff JH, Hwang SY, Duncan RS, Ozawa F, Volpe P, Inokuchi $\mathrm{K}$ and Koulen $\mathrm{P}$ : Vesl/Homer proteins regulate ryanodine receptor type 2 function and intracellular calcium signaling. Cell Calcium 34: 261-269, 2003. 